\title{
Tackling food systems from a broad spectrum
}

\author{
Review by Cassandra Hawkins* \\ Mississippi Valley State University
}

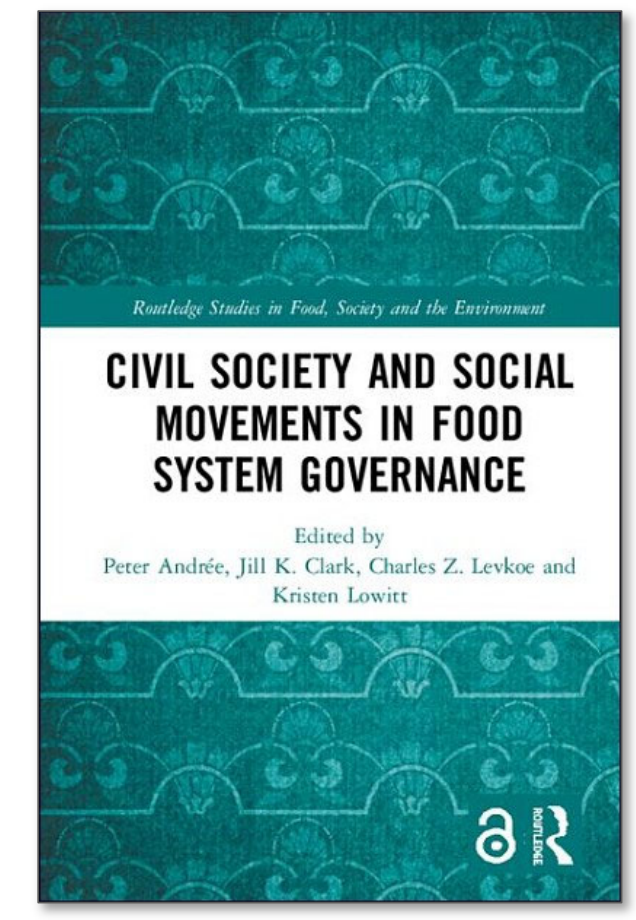

Review of Civil Society and Social Movements in Food System Governance, edited by Peter Andrée, Jill K. Clark, Charles Z. Levkoe, and Kristen Lowitt. (2019). Routledge. Available as open access ebook and hardcover; 216 pages. Publisher's website: https://www.routledge.com/Civil-Society-and-SocialMovements-in-Food-System-Governance/Andree-Clark-LevkoeLowitt/p/book/9781138588073

Submitted March 18, 2020 / Revised April 8, 2020 / Published online February 22, 2021

Citation: Hawkins, C. (2021). Tackling food systems from a broad spectrum [Book review].

Journal of Agriculture, Food Systems, and Community Development, 10(2), 579-581.

https://doi.org/10.5304/jafscd.2021.102.040

Copyright (C) 2021 by the Author. Published by the Lyson Center for Civic Agriculture and Food Systems. Open access under CC-BY license.

$\mathrm{T}$ hrough an in-depth exploration of food movement actors' capabilities to transform decision-making from local to international levels, the authors of Civil Society and Social Movements in Food System Governance examine the significance of their involvement, while exploring the intersectionality of governance, social movements, and systems thinking. The premise of the text sets a tone for the need to fully understand the trajectory of food

* Dr. Cassandra Hawkins, Program Coordinator, Master of Arts in Rural Public Policy and Planning; and Assistant Professor of Rural Public Policy, Rural Public Policy and Planning, Department of Social Sciences; Mississippi Valley State University; MVSU 7227, 14000 Hwy 82 West; Itta Bena, MS 38941-1400 USA; +1-662-254-3361; cassandra.hawkins@mvsu.edu systems governance, especially since food systems movements are gaining significant momentum at the local, regional, and international levels. The editors note that "these movements seek to reinforce, build on, and scale up innovative, placebased initiatives" (p. 1).

Many of the chapters stem from the work of

Dr. Cassandra Hawkins is the program coordinator for the master of arts Rural Public Policy and Planning program and an assistant professor of rural public policy and planning/ public administration in the Department of Social Sciences at Mississippi Valley State University. She is also a program evaluation consultant with Hawkins \& Associates, LLC. Her research interests include program evaluation, student pedagogy, American literature, agriculture policy, rural policy, socially disadvantaged farmers and ranchers, food systems change, and food insecurity in Mississippi. 
the Food: Locally Embedded Globally Engaged (FLEdGE) action research collaborative. Many researchers and program evaluators, like myself, understand that action-oriented inquiry is key to understanding food systems throughout the world. FLEdGE provides an opportunity for community partners and researchers through this book as a means of inspiration, motivation, and transformation of food systems. Through the work of FLEdGE, collaboration provides an avenue for sharing knowledge and research capital for sustainable change through its robust network of stakeholders interested in food systems work across the world. Thus, this book provides a glimpse into FLEdGE's commitment to food systems change.

The diverse backgrounds of the authors contributed to the value of this book. For example, among the 16 contributors, six are practitioners. Having such an extensive number of practitioners contribute to a book on food system governance was fascinating. In many food systems, practitioners contribute more to the transformation than academicians. But since they focus more on grassroots efforts than on publishing, their viewpoints are not always shared. Oftentimes, academicians report on the work that practitioners are doing in their communities or within specific food systems, like in Mississippi, where the prevalence of food insecurity affects so many households. This book's inclusion of contributions from both academics and practitioners creates a wealth of knowledge to understand governance among contemporary food systems. For example, Chapter 7, Indigenous SelfDetermination and Food Sovereignty through Fisheries Governance in the Great Lakes Region, includes five contributors, three of whom are practitioners. Furthermore, this chapter includes a discussion about Indigenous people from practitioners who are members of the Indigenous community. The contributors know first-hand how governance is affecting their food systems, and the readers are exposed to the viewpoints of both researchers and community partners. Readers are shown the applicability of the theories that are discussed through the lenses of the practitioners.

Instead of continuing the trend of only identifying challenges that affect the governance of food systems, Civil Society and Social Movements in
Food System Governance creates a unique experience that includes discussions of opportunities and implications. For example, chapter 5 provides examples for community partners and researchers to fully grasp what opportunities could be available in food systems and how policy directly affects food movements. Researchers and practitioners gain valuable insight about government-led policymaking processes and can further use this information to inform significant food systems change. Additionally, this chapter provides important insight on how to effectively influence food policy, despite the tension and different goals and objectives among the stakeholders. This unique spin on discussing food system governance proves to be very useful for food movement actors and addresses the gap in the food systems literature about opportunities. Furthermore, Civil Society and Social Movements in Food System Governance demonstrates the critical role that governance, social movements, and system thinking play in the ultimate transformation of contemporary food systems.

Civil Society and Social Movements in Food System Governance contributes to readers' understanding of governance processes within a food system. Readers are prompted to reflect on the food movements affecting their surrounding communities. By discussing specific cases, readers are exposed to the way that food systems on the local level experience transformation. This book also sheds light on the significance of co-governance in food systems transformation. Contributors present an intense argument that co-governance remains necessary to create a consensus among all stakeholders within a food system. This can be applied to food systems in Mississippi and promote collaboration among community partners, political figures, community members, and researchers. Many chapters illuminate how power-sharing mechanisms contribute to co-governance in food systems. For example, chapter 5 outlines initiatives that include co-governance in a collaborative policy-making infrastructure.

I highly recommend that researchers and community partners, especially those working in food movements, read this book. It could help food movement actors to examine their own impact in decision-making in their current food systems. Since the text includes such an abundance 
of information related to a variety of governance innovations, it could be used as a guide to continue transforming contemporary food systems. Food movement actors are not the only benefactors of this book. Because it covers a variety of topics, including polycentrism and self-governance, researchers, students, policy-makers, and community members can benefit from reading it. For example, the introduction of Civil Society and Social
Movements in Food System Governance explains how the authors define the concept of food movements. The explanation provides a basis for a variety of stakeholders to understand the interconnectedness of the different elements that compose a food system, including movements and initiatives. This interconnectedness also alludes to how political forces and diversity impact food systems. 